\title{
PROBLEMS AND TASKS OF MUNICIPALITIES OF THE RUSSIAN FEDERATION IN PROCESSING AND UTILIZATION OF DOMESTIC WASTE
}

\author{
Sergey Kirsanov ${ }^{I}$ \\ Irina Luchkina ${ }^{2}$ \\ 'St. Petersburg State University of Engineering and Economics, Russia \\ ${ }_{2}^{2}$ Municipality of Kolpino, Russia
}

\section{EXTENDED ABSTRACT}

In Russia there is a great deal of firm industrial waste. The polluted area is more than 200000 hectares. Dumps have a huge negative influence on the atmosphere and ground, pollutes overground and ground water. Quantity of waste rapidly increases but level of field of utilization is still very law. The range of a firm waste processing in Russian Federation is low comparing with EU countries.

The field of use, neutralization, storage and burial of waste leads to a dangerously pollution of environmental, irrational use of natural resources and becomes a real danger for the future generations. Annually in RF appear about 70 billiards tones of waste and only $30 \%$ are used. Thousands of hectares of lands (without paying any attention on the areas using as illegal dumps) are chosen for ranges of firm waste every year.

There is no effective state policy of a field of using waste till nowadays. In this difficult situation the part of local authorities increases. They should follow a far-seeing policy to appreciate the usage of waste and decrease of their negative influence on an environmental.

According to Russian Federation's Federal Law "About common principles of local authorities organizing in Russian Federation" № 131-FZ, 06.10.2003 municipalities are accountable for gathering, taking away, neutralization and processing of waste.

There is no steady development in Russia and there are some reasons for that: missing comprehension of the necessity of a financial support environment's protection and renewal. The most programs for saving resources are oriented on solving short-term problems and do not pay attention on real sources of finance, production costs and possibilities of borrowed funds' payment.

One of the most important conditions of rational consumption of raw material resources is a complex processing of waste. The complex usage of resources by combining different kinds of manufactures could provide using one manufactures' waste as a raw material for another one. Specialists believe that raw material usage is possible by combining several processing 
enterprises. Hence, for rational usage of raw material resources by municipalities it is necessary to form joined inter-branch municipal enterprises.

Formation of municipal industrial-economic systems involving different kinds of enterprises needs making a common technological line. In this case is possible to make a technology involving technologies of several industries located within an area of the municipal formation and combined by the task of usage raw material with lowest costs. These technologies should have a common feature - maximum usage of starting sources with the least costs. This way of processing of material and energetic resources promotes cutting down of raw material, material and energetic loss; cuts down transport costs and man-hour; extends the range of products produced of using raw material.

A municipality's conception of complex management of waste should contain the following points proved by experience of other countries as following:

- there isn't the only one technology which is possible to process the whole stream of waste without any danger for people's health and environment,

- even a complex of technologies will lead to solving a problem if this complex is used with economic and social steps.

A political situation nowadays provides municipalities with independence in different ways and makes opportunities for realization of this concept.

Components of efficiency of the organization of gathering of secondary raw material.

From the point of view of the state:

- reduction of usage of natural resources due to their replacement by secondary resources in various technological processes;

- improvement of ecology of territory by decrease the quantities of waste exposed to burning and a burial;

- reduction of social intensity due to granting to poor levels of the population the opportunity to have additional incomes from delivery of secondary raw material;

- improvement of raw material supply of manufactures using secondary raw material;

- reduction of goods' prices in consumer market due to decreasing of prices of their production taking into account the usage of secondary resources.

From the point of view of proprietors of the enterprises:

- the incomes received as a difference between the price of secondary resources' sale by the processing enterprise and by their purchase from the population;

- the incomes received from sale to the population the subjects of home appliances handed into places of acceptance but repaired after that.

From the point of view of the population:

- reception of additional incomes by those who hands in secondary raw material into places of acceptance;

- improvement of a sanitary condition and aesthetic shape of city that is important for all population.

At the moment in Russia in sphere of processing of waste basically operate large enterprises formed as state or municipal unitary enterprises, less often - joint-stock companies with participation of the state. As a rule these enterprises are remarkable for stagnancy concerning applied technologies, possess the out-of-date equipment and the personnel of low qualification; these enterprises have the lowest productive effectiveness as a result of application of the underestimated tariffs. For example, processing of domestic waste on 
processing factories of St.-Petersburg MPBO-1 and MPBO-2 is carried out on the technology developed in the beginning of 70th years of 20 century. That time it was a high technology, but today it sharply requires improvement; and the enterprises require modernization of manufacture. Because of discrepancy of the established tariffs to real expenses and imperfections of market of the products of secondary processing, the means which are possessed by enterprises are enough only for maintenance of technological process.

Experts approve that it is impossible to make Northern capital and Leningrad region to be cleaned until both subjects will not coordinate actions in field of recycling and processing of firm domestic waste. St.-Petersburg annually produces more than 5 million square meters of domestic waste. There are two processing factories and three ranges; though within city's teritory numerous illegal dumps are located nevertheless the situation is under the control. In Leningrad region $99 \%$ of waste is placed on dumps. And the majority is located in places unadapted to this purpose: in former sandy open pits, peat excavations and even in city. Poisoned dump drains get into ground water and are carried by underground horizons, being threat for local population.

Formation of megapolises and constantly increasing people's economic activity creates one of the sharpest problems of 21 century. It is a problem of protection of environment from negative influence of production waste and consumption.

In Russia problems with rubbish were solved and still are solved simply: the rubbish is taken to uninhabited places and cocked. Today only in St.-Petersburg ranges occupy more than 530 hectares - almost four times more than area of Monaco. The most ranges do not comply with required norms. Almost all of them have turned to ecologically dangerous objects: mountains of dust allocate carbonic oxide, methane and other compounds. Plus pathogenic microorganisms, and also eternal satellites of dumps - rodents.

The main problems of St.-Petersburg and Leningrad region in sphere of the reference with waste:

1. Pollution of territories by the toxic substances washed away or allocated from congestions of waste: pollution of ground, water, air; reduction of recreational territories, agricultural grounds;

2. The scheme of gathering of waste and material equipment in sphere of the reference with waste doesn't correspond with real needs: lack of capacities for industrial processing waste (only $30 \%$ of waste of St.-Petersburg are processed at factories of $\mathrm{MPBO}$ ); a greater degree of deterioration of the equipment at factory of MPBO-1;

3. Absence of appropriate system of the account of waste: absence of unified informational- reference system under the reference with waste, the weak control over formation of waste and their movement;

4. The inefficient tariff policy: tariffs for a burial place of waste for ranges below, than for processing at factories of MPBO, tariffs for a burial place of waste in Leningrad region below, than in St.-Petersburg, distribution of financial assets between carriers and those who processes waste requires correction (transportation of waste is paid more expensive, than processing more than twice);

5. Imperfection of acting legislative and normative base: the "Pollutant Pays" principle in many cases is not observed, the absence of the legislative base based on joint participation of St.-Petersburg and Leningrad region as two subjects of Federation in the decision of the general problems. 
6. Low efficiency of use of a fixed capital; practically there is no organizational, economic support of an infrastructure of secondary use of materials.

7. Technological problems: the park of containers and dust-carts has the big percent of deterioration; there is no organizational selective collection of dangerous waste and secondary raw material; there are no platforms on collection large-sized waste, bodies of motor vehicles and tires; $27 \%$ of firm domestic waste are exposed to industrial processing; ranges $\mathrm{PTO}-1$ and $\mathrm{PTO}-3$ require modernization.

To change a situation, it is required to revise in principle the approach to the organization of system of processing of waste: introduction of economic stimulus, expansion of number of the enterprises, rendering services on processing waste, development and introductions of new technologies, attraction of investments for development of manufacture.

One of the problem on activization of innovative activity in sphere of processing of firm waste and extraction of advantage from secondary resources is attraction a private business in sphere of secondary processing which differs a greater flexibility and mobility concerning introduction of new technologies. This problem should be solved both on municipal and on regional levels.

Controls of MD should provide:

- Licensing for realization of enterprise activity;

- Realization of the thought over tariff policy in sphere of processing of waste;

- To assist businessmen in reception of soft loans, in registration of the equipment in leasing;

- To promote personnel maintenance of again created enterprises on processing waste, solving simultaneously problems of employment of the population of municipal formation;

- To organize in bodies MSU the structural divisions responsible for work with private businessmen;

- The control over observance by the enterprises of the established legislative norms.

At a regional level it should be provided:

- Legislative base of development of business in sphere of processing of waste by acceptance of the certificates defining the mechanism of registration of tax privileges and soft loans, reception of licenses;

- Conducting a uniform information databank of technologies of processing of waste and variants of use of products of the secondary processing, allowing businessmen to receive data on capital and current expenses, a level of potential incomes.

Development of business in sphere of processing of waste will allow to solve a lot of the problems connected with growth of volumes of waste made in St.-Petersburg. And first of all: improvement of ecology of territory of $\mathrm{MD}$, owing to perfection of system of sanitary clearing at a stage of processing of waste; acceleration of process of modernization of sphere of processing of waste; increase in profitableness of the enterprises in sphere of processing of waste; increases in a variety of the products made from secondary materials.

The whole industry on processing secondary household waste operates in the European countries, and this business is considered unprofitable in Russia because it is badly supported by institutions of local government. For example, questions of tap of the grounds are solved 
slowly. Preliminary design and design works manage very expensive, and not each enterprise presumes such expenditure. Potential investors refuse participation in projects in which it is possible to issue rent of the ground areas only for 5 years. Stable prospects for longer period are necessary. Creation of the intermunicipal Center on coordination of enterprise activity in sphere of processing of waste can become one of directions of activity of municipalities. Such Center will promote cooperation of the municipal enterprises with the small enterprises operating in this sphere. It can be any form of subcontract attitudes.

Now small business in sphere of ecology does not have enough space for self-realization. Cleaning of territories, processing of domestic waste is municipalized. And the municipal enterprises do not wish to have competitors. Small business in sphere of ecology should have concrete state and municipal support. Stimuli for participation of small enterprises in gathering dust, sorting of waste for the further processing are necessary. It is necessary to enter the simplified system of passage of the documentation for small enterprises. It's important to create in this sector the real market at a level of municipal authorities. There will be a market - there will be investments.

The obvious fact is that municipal formations should have one system of processing of waste. After the careful technical and economic assessment should build processing factories and factories of burning of dust.

The problem of the intermunicipal unions of region - construction small factories of processing of dust. Besides it is necessary to finish the reconstruction of factory MPBO-1 in St.-Petersburg with expansion of capacities to 8 million $\mathrm{m} 3$ in a year.

The factors dictating necessity of reconstruction of experimental plant MPBO-1:

- Increase in operational expenses and decrease in an overall performance of a factory as a whole in view of significant deterioration of the equipment (the factory is in operation more than 30 years);

- Unsatisfactory quality of compost received;

- Installation of additional gas purification;

- With increase in capacity of processing of waste a loading on other operating ranges will sharply decrease at a factory;

- Increase of volumes of formation of waste in St.-Petersburg (volume of TBO in 1995 has made 5 million $\mathrm{m} 3$, predicted quantity of बBO in $2005-8$ million $\mathrm{m} 3)$;

- Necessity of the speedy increase in the mechanized processing of domestic waste in view of the low interest of volumes of processing of domestic waste.

Experience of nature protection activity shows that environmental problems are rather complex and cannot be solved in one step. First of all limiting factors are economic opportunities of municipal formation. Therefore nowadays the main problem - stage-by-stage creation the resource-saving technologies providing decrease of quantity of waste and economy of financial-power resources.

Domestic and foreign experience convince that well-timed investments into nature protection activity could be in some times less than those means which a society spends for completion of the plotted damage. 
The capital of an investment on these purposes by some estimations pay off in 1,3 times more quickly, than as a whole on a national economy. For this reason, reduction of charges of resources gives significant economic and ecological effects.

Mobilization of investments of a private sector in sphere of ecology should become one of the major directions of activity of local authorities. Investments into sphere of processing of domestic waste, which consider both ecological, and economic aspects, including conservation of energy, wasteless systems in a municipal economy, are the most effective.

The policy of preservation the environment from the pollution, based on neutralization of waste, should give a up the place to the policy of resource saving, based on complex use of raw material, the maximal involving in economic circulation of the secondary resources, the accelerated introduction of low-wasted technologies and utilization of waste. 